\title{
Comunhão do masculino e feminino em contos de Mia Couto
}

\section{Communion of the masculine and feminine in Mia Couto's short stories}

\author{
Francisca Kellyane Cunha Pereira \\ https://orcid.org/0000-0001-6202-0574 \\ Tércia Costa Valverde \\ https://orcid.org/0000-0003-3494-7043
}

Resumo: No presente estudo, buscamos investigar como ocorre a dissolução das dicotomias de gênero e a convergência de características masculinas e femininas, em personagens de três contos de Mia Couto. A partir dos mitos e símbolos moçambicanos e universais, o autor apresenta personagens que unem masculinidade e feminilidade, capazes de tocar o leitor ocidental por seu caráter humanístico. Masculino e feminino se completam e fazem parte da psique de todo indivíduo, entretanto, as diversas mitologias criaram símbolos que se contrastam e se opõem. A linguagem, as narrativas e os textos não descrevem coisas aleatórias, mas instituem as ideias e inventam as identidades. Sendo assim, o que acontece em Moçambique, a subalternização, marginalização e o silenciamento, principalmente do feminino, representam os reflexos de uma História, que carrega um discurso cultural. O corpus é composto pelos seguintes contos: Mulher de mim (1990), Ezequiela, a humanidade (1990) e Joãotónio, no enquanto (2012). Para o embasamento teórico, utilizamos a teoria dos arquétipos de Carl Jung (2008) e textos de Gaston Bachelard (1996). Sobre a escrita de Mia Couto, o arcabouço teórico de Fernanda Cavacas (2015), Maria Nazareth Fonseca (2008), Rita Chaves (2013) e Ana Mafalda Leite (2013).

Palavras-chave: Mia Couto; Feminino; Masculino; União.

Abstract: In the present study, we sought to investigate the dissolution of gender dichotomies and the convergence of masculine and feminine characteristics in Mia Couto's three short stories. From the Mozambican and universal myths and symbols, the author presents characters that unite masculinity and femininity, capable of touching the Western reader by its humanistic character. Masculine and feminine are complete and are part of the psyche of every individual, however, the various mythologies have created symbols that contrast and oppose each other. Language, narratives, and texts do not describe random things, but instill ideas and invent identities. Thus, what happens in Mozambique, subalternization, marginalization and silencing, especially of the feminine, represent the reflexes of a History, which carries a cultural discourse. The corpus is composed of these stories: 
Mulher de mim (1990), Ezequiela, a humanidade (1990) and Joãotónio, no enquanto (2012). For the theoretical basis, we use the theory of archetypes by Carl Jung (2008) and texts by Gaston Bachelard (1996). On the writing of Mia Couto, the theoretical framework of Fernanda Cavacas (2015), Maria Nazareth Fonseca (2008), Rita Chaves (2013) and Ana Mafalda Leite (2013).

Keywords: Mia Couto; Female; Male; Unity.

\section{Masculinidade e feminilidade}

A obra de Mia Couto desestabiliza os valores tradicionais e paradigmas sociais, desconstruindo a ideia de sujeito cartesiano. Essas outras perspectivas desmontam a visão binária dos gêneros e nos leva a uma dimensão reflexiva sobre os papéis sociais do homem e da mulher, na sociedade moçambicana. A ficção de Mia Couto problematiza, criticamente, as construções do feminino e do masculino, para compreender e trazer à luz questões sociais. Dessa forma, as situações insólitas narradas, que impactariam, inicialmente, o leitor, acabam sendo, posteriormente, compreendidas, podendo nos aproximar do outro, ainda que diferente, por seu caráter humanista. As personagens exercem papeis que contrariam as expectativas sociais, fogem do "padrão de normalidade", nos sensibilizando para a necessidade de uma mudança nas relações sociais.

Sua obra não repete os estereótipos africanos, pois o autor traz as marcas de seu país ao mesmo tempo que trata de temáticas universais, como: identidade, solidão e medo. Por meio de uma linguagem que simula a oralidade, Mia Couto cria uma língua literária própria. Além disso, seus personagens são sujeitos excluídos e marginalizados, que tomam o centro da narrativa e do discurso, fazendo com que o leitor reflita sobre questões sociais presentes em qualquer sociedade contemporânea.

A plasticidade da linguagem refeita permite esboçar o caráter dos personagens, além de desafiar os limites de raça e gênero. Delineia-se então que o caminho traçado por Mia Couto não é de ações concretas, certezas ou afirmações. Em sua obra, os espaços, personagens e provérbios não se firmam no mundo real e reconhecível, mas sim na dúvida e questionamentos. O leitor fica com a reflexão existencial e não com a concretude e as certezas culturais.

Os mitos, contos e lendas do imaginário comum refletem e reforçam os arquétipos de pertencimento e construção dos seres masculinos e femininos. De acordo com António Domingos Braço (2014, p. 261), as diferenças sexuais só podem ser explicadas dentro dos sistemas de significação, pois em sociedades tradicionais toda ação social é também cultural. 
Dessa forma, os papéis sociais próprios aos homens e às mulheres têm raízes nos discursos culturais. O autor nos diz ainda que, de um lado, existem as macronarrativas, teorias sociais e culturais que constroem, ao longo do tempo, a diferenciação entre os gêneros. Mas, por outro lado, há as micronarrativas, lendas, contos e ritos que as pequenas comunidades utilizam para explicar essa diferenciação. Assim, as desigualdades de gênero estão construídas no plano simbólico.

A construção de imagens no plano simbólico ou mitológico é tão ou mais forte do que no plano social, pois esses imaginários são passados sem que possamos perceber, tratando-se de ideias muito difíceis de serem desconstruídas. Desde a infância, somos inundados de narrativas que ditam o que se espera do sujeito masculino e do feminino, delimitando os espaços, profissões e comportamentos esperados. Para Pierre Bourdieu (2002, p.15), o sistema mítico-ritual:

Desempenha aqui um papel equivalente ao que incumbe ao campo jurídico nas sociedades diferenciadas: na medida em que os princípios de visão de divisão que ele propõe estão objetivamente ajustados às divisões pré-existentes, ele consagra a ordem estabelecida e reconhecida, oficial.

Essa naturalização das diferenças entre os gêneros é sutil e acaba por moldar desde a infância, interferindo na formação da identidade e responsabilidades sociais dos homens e mulheres. De acordo com Le Breton (2009, p. 67), A configuração distintiva dos sexos separa desde a infância meninos e meninas, preparando-os para um papel futuro dependente dos estereótipos do feminino e do masculino. Esse encorajamento reitera a doçura para as meninas e a virilidade ao lado masculino. Além disso, a tradição oral, por meio de provérbios e contos, não está presa ao passado, tendo força no presente em todos os espaços. Para Braço (2014, p. 264),

\begin{abstract}
A desmistificação das relações de poder, entre o feminino e o masculino poderia resultar da compreensão da tradição oral, de como os discursos foram sendo ordenados e nos modos de como esses ordenaram os espaços da mulher e do homem na sociedade.
\end{abstract}

Cabe ressaltar que o mito é uma narrativa. Entretanto, difere-se das demais conduções discursivas, pois seria tragado pelo oceano das narrativas. Trata-se de um fato que, sob forma alegórica, deixa entrever um acontecimento natural, histórico ou filosófico. O próprio mito é uma tradição que carrega em si uma mensagem cifrada, algo que não está dito, diretamente. 
Entre outros aspectos, destaca-se que o mito funciona socialmente, sendo repassado e presente na vida social de um povo.

Na mitologia, nos contos de fadas, folclore e poesia das diversas comunidades, vemos representações da psique do homem moderno. Gigantes, anões e duendes são elementos comuns em lendas de qualquer lugar do mundo. Pensando na natureza feminina, percebem-se também diversos seres representativos (JUNG, 2006, p.58). Entes provocantes, de beleza arrebatadora, mas apenas meio-humanos. Estes seres sempre estão ligados a algo sinistro, um tabu que não pode ser ultrapassado.

A teoria dos arquétipos de Carl Jung (1995, p. 14) define os aspectos femininos e masculinos dos sujeitos. De acordo com o autor, o anima seria inconscientemente a personificação dos aspectos femininos no homem e o animus seria a personificação dos aspectos masculinos no inconsciente da mulher. Ligado às mulheres, o anima é conduzido pelo princípio da vinculação, do relacionamento, do eros e da subjetividade. Já o animus, como os homens, é gerido pela razão, pelo logos, pela palavra e pela objetividade. Não há uma limitação daquilo que é masculino ao homem e do que é feminino à mulher: "Estão sempre presentes em determinada medida, mas que são incômodos para a adaptação externa ou para o ideal existente." (JUNG, 1995, p. 15).

\section{A arrogância das metades}

Tendo como enfoque o personagem do conto Mulher de mim (1990), podemos observar algumas questões sobre identidade feminina e masculina, e como elas se chocam e se completam. Na narrativa, o narrador, que não possui nome nem características físicas, está em um quarto de hotel, que também é descrito de forma genérica, em um estado entre o sono e a vigília. Inesperadamente, entra em seu quarto uma mulher que, inicialmente, desperta-lhe desejos sexuais, mas não chegam a consumar o ato. Quando a mulher sai do quarto, o homem começa a se questionar sobre quem é aquela estranha e passa a crer que ela não é desse mundo dos "viventes". No encerramento do conto, a mulher misteriosa volta, pedindo um lugar dentro dele, já que ela é seu lado feminino.

Traços referentes ao comportamento feminino, como o choro e as emoções aparecem nessa visitante. A visão da narrativa se dá a partir do narrador. As experiências são dele e de seu ponto de vista. Para Carlos Reis (1988, p. 63), o narrador, enquanto protagonista, é detentor de uma voz, sendo capaz de intrusões, vestígios de sua subjetividade e que apresentam uma 
apreciação particular daquilo que é relatado. O autor destaca ainda a distância temporal entre o passado da história e o presente da narração. Em Mulher de mim, há uma simultaneidade entre a narração da história e o monólogo interior do personagem. Além disso, podemos observar que o sujeito presente já não é o mesmo que viveu os fatos relatados, centrado no interesse desse relato. Segundo Carlos Reis (1988, p. 119), nesse tipo de narração:

\begin{abstract}
A opção por uma focalização interna ou por uma focalização onisciente relaciona-se, pois, com uma certa imagem privilegiada pelo narrador; privilegiando a imagem do personagem, o narrador reconstitui artificialmente o tempo da narrativa da experiência, os ritmos em que ela decorreu e as atitudes cognitivas que a regeram, ao mesmo tempo que abdica da prematura revelação dos eventos posteriores a esse tempo da experiência em decurso.
\end{abstract}

No conto investigado, encontramos um narrador personagem, em um quarto de hotel, no momento entre o sono e a vigília. O momento em que a estória se dá nos coloca em um ambiente onírico. Aqui, o tempo não é exato, ficando sempre na imprecisão. Esse instante entre o sonho e o despertar é comparado ao nascimento: "Acordar não é a simples passagem do sono para a vigília. É mais, um lentíssimo envelhecimento. (...) E concluí: a vida, ela toda, é um extenso nascimento" (COUTO, 2013, p. 127). Aqui, o movimento entre adormecer e despertar gera uma instabilidade, na qual o que interessa para a narrativa é a experiência de sonhar. Nesse espaço, o narrador diz e torna possível ser dito. A circunstância de que a mulher the aparece pela primeira vez durante o sono indica a anima - como sua metade.

Para Bachelard (1996, p. 54), o sonho pode ser uma luta violenta ou manhosa contra as censuras. No devaneio solitário, podemos dizer tudo a nós mesmos, assim, nos conhecemos, ao mesmo tempo, no masculino e no feminino. Jung demonstrou que o psiquismo humano tem uma natureza andrógina. Segundo o mesmo autor, o inconsciente não é feito de lembranças esquecidas, mas sim é a natureza primeira (BACHELARD, 1996, p. 55). Não há tranquilidade no monolitismo paralelo do masculino e do feminino integrais. O tempo trabalha todas as coisas: dia e noite, as estações, as idades, não deixando nossa androginia tranquila. Bachelard argumenta que:

Não se trata, aliás, de uma dialética verdadeiramente paralela, que opera num mesmo nível, como a pobre dialética dos sim e dos não. A dialética do masculino e do feminino se desenvolve num ritmo de profundeza. Vai do mesmo profundo, sempre menos profundo (o masculino), ao sempre profundo, sempre mais profundo (o feminino). E é no devaneio, "na inexaurível reserva de vida latente", como diz Henri Bosco, que vamos encontrar o 
Retoma-se, em Mulher de mim, o mito do Andrógino, uma completude de forças: Masculino e feminino. Na Grécia antiga, as discussões de Filosofia Clássica tratavam de uma terceira imagem de gênero, que Platão nomeia de Androginia. Em O Banquete, o filósofo nos descreve esse ser que reunia, na forma e no nome, características de ambos os gêneros masculino e feminino -, constituindo um gênero distinto. Essa criatura era redonda: seus lados formavam um círculo e ela possuía quatro mãos, quatro pés e uma cabeça com duas faces exatamente iguais, cada uma olhando numa direção, pousada num pescoço redondo. Sua força era extraordinária e seu poder, imenso, tornando-os ambiciosos. Zeus resolve cortá-los ao meio e fazê-los andar sobre duas pernas, para diminuir sua força e torná-los mais humildes. Eternamente insatisfeitos e incompletos, os andróginos - agora homens e mulheres - passaram a procurar suas metades.

A união dos opostos leva à plenitude. A convivência harmônica dos traços femininos e masculinos trazem a completude do sujeito, sua unidade primordial. No início da narrativa, o narrador se compara a uma pedra de gelo, mostrando-se flexível e mutável: “A pedrinha de gelo me semelhava, ambos nós transitórios, convertendo-nos na prévia matéria de que nos havíamos formado" (COUTO, 2013, p. 127). O narrador sugere uma relação entre a feminilidade e a água, relacionando o poder de sedução daquela mulher com o regresso ao "murmurinho das fontes". Essa analogia com a pedra de gelo remete ainda à rigidez masculina, que nessa conversão de matéria deixa de existir para dar espaço à feminilidade. Assim, a solidez de sua masculinidade cede lugar para a fluidez do feminino que, como a água, é maleável e adaptável.

Mia Couto propõe uma relação entre a feminilidade e a água em muitos escritos. Aqui, o narrador luta, inutilmente, em se manter sólido, masculino e em unidade. Entretanto, o aspecto feminino e mutável o contagia. A personagem, descrita como: "uma mulher de olhos lisos que humedeciam o quarto" (COUTO, 2013, p. 127), traz em si o apelo da água. Ele, simbolizado pelo sólido, porém transitório cubo, anuncia a efemeridade de seu lado masculino. A água e o ventre materno são simbolicamente associados, pois na busca de encontrar as origens, o narrador afirma que: "a gente vai transitando do útero para a casa, cada casa não sendo senão outra edição do útero materno" (idem, p. 131). Aquela intrusa relembrava o narrador que ele jamais conseguiria regressar ao primordial lugar, pois estava preso aos constrangimentos rígidos de seu mundo racional.

Ao mesmo tempo, o que fecha essa transição de água e gelo é o regresso. Para sentirse completo, o narrador vê a necessidade de voltar ao princípio primitivo, ou seja, retornar aos 
primórdios da existência e, assim, ser completo novamente. A misteriosa mulher não lhe traz novidades, mas sim, sentimentos "do murmurinho das fontes", "do regresso a dantes quando não havia antes", "de antiquíssima esposa" (COUTO, 2013, p. 128).

Esse retorno ao começo de tudo é o que pode trazer completude ao narrador. Naquela mulher estava o que lhe faltava: "Sem eu ser ela, eu me incompletava feito só na arrogância das metades" (COUTO, 2013, p. 133). Em vez de buscar uma mulher para preencher seu vazio, o narrador espera se completar com seu lado feminino, a mulher dentro dele. O mito do andrógino se completa, pois, as duas metades voltam a se unir: "E assim deitado, todo eu, escutei meus passos que se afastavam. Não seguiam em solitária marcha, mas junto de outros de feminino deslize, fossem horas que, nessa noite, me percorreram como insones ponteiros" (COUTO, 2013, p. 133). A figura primitiva do mito clássico do andrógino se completa. Os passos do narrador agora são acompanhados de passos femininos. A mulher dentro dele passou a ocupar seu lugar, pois, para ser inteiro, ele necessita ser masculino e feminino, ao mesmo tempo.

A linguagem simbólica na obra de Mia Couto ajuda a compor a imagem desse terceiro gênero. Vemos uma terceira via, que surge como possibilidade de inserção nas relações sociais de gênero. Utilizando o pensamento de Teixeira (2016, p. 39), ao falar da androginia em Diadorim, de Grande Sertão: Veredas, aqui, dilui-se a visão binária, em que se lê o homem oposto à mulher, masculino oposto ao feminino. As duas margens desembocam na transformação, reenviam-se uma à outra, possibilitando um terceiro ponto de vista. Seria a assunção de um ser híbrido, capaz de abarcar as duas metades e evocar sua condição de totalidade.

De acordo com Phillip Rothwell (2015, s/p), observa-se o desaparecimento da categoria "finito", pois, a ordem binária dos gêneros, na qual homem se opõe à mulher, é questionada nessa narrativa. Essa dicotomia, sempre reproduzida em todas as esferas humanas, torna-se artifício que parece natural. Em vez de apresentar um gênero dominando o outro, Mia Couto sugere uma complementariedade mútua, onde o narrador precisa daquela mulher, e ela só existe nele.

Podemos retomar ainda a teoria de arquétipos da psicologia Junguiana: Anima e Animus. No conto Mulher de mim, o narrador nos apresenta seu anima. Aquela mulher não precisa escutar a razão, isso seria o papel dele enquanto homem, conforme podemos observar no seguinte trecho: "Precisava pensar rápido: ela gozava a vantagem de não precisar de consultar a razão. Eu devia encontrar, súbito, a saída do momento" (COUTO, 2013, p. 131). Se os elementos relacionados à razão pertencem ao homem, e naquele encontro no quarto de hotel, o narrador se depara com seu lado feminino, a subjetividade tenta dominá-lo. Sua 
consciência passa a desaparecer, a se "irrealizar", pois esse momento é movido pelo irracional. O anima do narrador se mostra ainda pelo uso e aceitação de elementos sobrenaturais, relacionados ao feminino. No retorno da mulher ao quarto, em vez de ser guiado por sua consciência, o narrador diz: "Me chegou por via de intuição" (COUTO, 2013, p. 131).

O narrador tenta apelar à razão, buscar ter o cérebro como "austero juiz", entretanto, desaparecia na presença daquela estranha intrusa. Sua masculinidade - animus - cede lugar à intuição, ao sonho e vozes ocultas. Os desígnios daquele encontro são apresentados no sonho e no silêncio. No sonho, é possível o encontro do sujeito com o estrangeiro de si mesmo. Destaca-se ainda o fato das relações entre vivos e mortos, razão e intuição se darem, através de personagens femininos, em outras obras de Mia Couto, como: O outro pé da sereia (2006) e $O$ último voo do flamingo (2000).

O conto investigado traz em si a problematização da identidade e a representação do masculino e feminino. Entre as várias dicotomias ressaltadas por Mia Couto, vemos a oposição entre vida e morte, que, assim como os gêneros, caminham juntas, em passo uníssono. A morte, a verdade e a profundidade são temáticas que envolvem o conto. Novamente, o sonho é destacado, agora pela semelhança com a morte, conforme podemos observar, no seguinte excerto:

$$
\begin{aligned}
& \text { Afinal: os mortos, os viventes e os seres que ainda esperam por nascer } \\
& \text { formam uma única tela. A fronteira entre seus territórios se resume frágil, } \\
& \text { movente. Nos sonhos todos nos encontramos num mesmo recinto, ali onde } \\
& \text { o tempo se despromove à omniausência. Nossos sonhos são senão visitas } \\
& \text { a essas vidas outras, passadas e futuras, conversa com nascituros e } \\
& \text { falecidos, na irrazoável língua que nos é comum (COUTO, 1990, p. 129). }
\end{aligned}
$$

É no sonho que se torna possível o encontro entre os vivos e os mortos. Seria uma espécie de "acesso provisório ao mundo dos espíritos", pois a morte é um extenso adormecimento, em que o espírito vaga e não consegue retornar ao corpo (CHAVES, 2012, p. 61). Não apenas no conto em análise, mas nas culturas tradicionais, como a moçambicana, observa-se essa relação. É nesse espaço do sonho que ocorrem os encontros espirituais, inclusive do sonhador consigo mesmo, pois, aqui, a razão não é necessária.

A vida moderna ensina-nos a refrear as manifestações de androginia. Entretanto, a tensão da civilização é tal que o feminismo costuma reforçar o animus na mulher. Em nossos devaneios, não nos prendemos aos tabus e determinações sociais. Nesse momento, nossa libertação é profunda e regida pela anima. Os sonhos estão sob o signo da anima, pois não carecem de racionalidade, ambição ou preocupação (BACHELARD, 1996, p. 58). Questões 
sociais ou culturais impõem que, nos homens, deve-se destacar o seu lado forte e, tipicamente, masculino, como aparece no seguinte trecho:

\begin{abstract}
As lendas antigas me avisavam: virá uma que acenderá a lua. Se resistires merecerás o nome da gente guerreira, o povo de quem descendes. Nem eu bem decifrava a lendável mensagem. Certo era que ali, naquele quarto, se executava a prova de mim, o quanto valiam meus mandos (COUTO, 1990, p.128).
\end{abstract}

O sonho é visto como símbolo de totalidade da vida, onde o sentido do sagrado atravessa o social, e a existência não se resume ao mundo visível (CHAVES, 2012, p. 59). No projeto literário de Mia Couto, percebe-se o mundo onírico como lugar de interação entre os sujeitos e o universo tradicional. Assim, reconhece-se que o sonho é "um espaço da imaginação, de realidade psíquica, mas um lugar de realidade social, de interação, de confluência do passado, presente e futuro, em muitas sociedades de tradição oral" (CHAVES, 2012, p. 64). No conto Mulher de mim, o narrador tenta ligar-se aos mandos culturais: "Vozes ocultas me seguravam: não, eu não podia ceder." (COUTO, 1990, p. 128). A fala dos ancestrais, por meio das lendas antigas, anunciavam que o narrador teria que resistir a essa mulher que "acenderá a lua".

A lua é a raiz de tudo que é yin, complementando o yang, representado pelo sol. No símbolo do TAO, as energias Yin e Yang se complementam, representando a plenitude e a perfeição suprema. Sendo a lua cheia relacionada à fertilidade e receptividade, Mircea Eliade (1991, p. 125) nos diz que, em escritos da China antiga, é a lua que faz com que diversos animais marinhos cresçam ou decresçam. Assim, quando aquela mulher mãe/amante surge para o narrador, não é apenas a surpresa de se deparar com seu lado feminino que o incomoda e angustia, mas o temor de que prevaleça a sua feminilidade, que, socialmente, deve ser reprimida. Destaca-se ainda que a mulher buscava nele espaço para se encontrar, conforme o destaque: "Procurava em mim espelho para o suave luar?". O narrador utiliza a metáfora da lua para simbolizar a presença feminina em si, como o reflexo de um espelho. Aquela mulher surge como uma sombra do narrador e seus olhos são inclusive partes dele, "saudosos" de si.

A narrativa se inicia com um provérbio do norte de Moçambique, do povo Macua, sociedade fortemente matriarcal. A epígrafe, na língua original: "Mulopwana, epaso; muthiyana, ehipa", refere-se à complementaridade dos sexos. A mulher, sendo a enxada, trabalha na produção agrícola da comida, alimentando a família. Já o homem, trabalhando com o machado, derruba as árvores e vai à caça. Não há uma diminuição do papel feminino ou masculino, mas uma complementariedade. Interessante destacar que, através de provérbios, são preconizados e transmitidos diversas normas e valores morais da sociedade. Tratam-se de verdades coletivamente aceitas, confirmando os saberes partilhados na comunidade. O provérbio 
escolhido por Mia Couto, diferente dos diversos ditados que definem a mulher como pertencente ao ambiente doméstico, mostra a figura feminina como parte de um trabalho externo e imprescindível na vida da comunidade.

As imagens do machado e da enxada vislumbram as representações sociais do masculino e do feminino, em Moçambique. Sendo instrumentos de trabalho, informam a utilidade prática e específica de cada sujeito. Os traços diferenciados marcam a perspectiva externa das identidades de gênero, na qual, ao homem, cabe a ação e destruição, enquanto, à mulher, a fertilidade. A respeito disso, Iza Quelhas (2001, p. 05) esclarece que:

O machado e a enxada, o primeiro vinculado ao trabalho humano (o corte) na sua verticalidade, associado às atividades de luta com o meio e com o outro, assim como abertura de caminhos ao próprio homem; o segundo, vinculado à imagem de cortes na terra, quando o corpo se curva num arco, horizontalidade das ações humanas favoráveis ao plantio e ao cultivo.

No encerramento do conto, a mulher misteriosa volta, pedindo não um lugar ao seu lado, mas sim um lugar dentro dele, já que ela é a mulher que faz parte dele: "- Não percebes? Eu venho procurar lugar em ti." Retoma-se então o mito do Andrógino, essa completude de forças, masculino e feminino. Esse conto nos faz crer na compreensão genérica do termo homem, moçambicano ou não, que para alcançar a plenitude, precisa conciliar ou (re)descobrir as porções dissemelhantes, mas complementares que nele coexistem. Aqui, o narrador fecha o ciclo, voltando à origem, a ser um ser inteiro, pois essa é a ideia do andrógino, como podemos observar no seguinte trecho:

Explicou suas razões: só ela guardava a eterna gestação das fontes. Sem eu ser ela, eu me incompletava, feito só na arrogância das metades. Nela eu encontrava não mulher que fosse minha, mas a mulher de mim, essa que em diante me acenderia em cada lua (COUTO, 2013, p.128).

Por fim, o conto se encerra da mesma maneira que começa: as horas passando vagarosamente, percorrendo o narrador, como "insones ponteiros". Ao utilizar as mesmas palavras, para iniciar e finalizar o texto, temos a impressão de um recomeço, retorno às origens. No "vagaroso apagar de mim", o declínio da luz sugere que é preciso, além de esquecer, aprender a despertar. $\mathrm{O}$ fim do conto não constitui um fim, mas sim um eterno começo, em que o narrador deve continuar uma eterna viagem, assim, o tempo apenas se arrasta. Os passos finais, bissexuais, sugerem que o processo é mais importante que o objetivo, pois ele deve aprender a caminhar, não mais "em solitária marcha, mas junto de outros em feminino deslize" (COUTO, 2013, p.133). Vale ressaltar que a temática desse conto não é tocante somente ao 
universo moçambicano, mas a qualquer homem contemporâneo. Podemos perceber a dimensão do que se delineia além do território e valores nacionais.

Mulher de mim não é o único conto de Mia Couto que traz personagens que são homens e mulheres, ao mesmo tempo. O conto Ezequiela, a humanidade também aborda essa temática, sob um viés fantástico. Presente no livro Na berma de nenhuma estrada, a narrativa se dá em terceira pessoa e conta a história de um rapaz chamado Jerónimo e seu amor por sua mulher, Ezequiela. Entretanto, havia uma peculiaridade nessa moça: de vez em quando, ela mudava de aparência. A mulher mudava de cor, cabelo e tamanho, transformando-se em outras, periodicamente. Apesar disso, Jerónimo aceita e ama sua esposa de todas as formas. Até que um dia, Ezequiela transforma-se em homem e isso acaba estremecendo a relação do casal. Em uma noite, Jerónimo adoece e Ezequiel o ampara, reacendendo o amor entre os dois. O inusitado ocorre quando, na manhã seguinte, Jerónimo não se reconhece frente ao espelho, pois ele e Ezequiela são agora um só.

A escolha do fantástico na escrita dessa narrativa não se trata de uma subversão intencional. A instauração da incoerência, diante do mundo racional e concreto, implica, segundo Flavio Garcia (2016, p.174), em uma estratégia discursiva. Nesse clima de aparente normalidade, vemos uma reflexão sobre o mundo real, e as suas múltiplas possibilidades.

Aqui, apesar do tom cômico, típico do autor, Mia Couto avança na busca da metade perdida, na completude andrógina. Mais que uma conexão mental, o conto sugere uma androginia física, biológica (CANTARIN, 2012, p. 149). Diferente do anterior, esse conto traz mais ambiguidade e dificuldade de interpretação, pois, o desfecho gera a possibilidade de Jerónimo também ser outro e não se reconhecer. Se Ezequiela possui em si uma infinidade de pessoas, no desfecho da narrativa, também Jerónimo estará dentro dela. Ressalta-se que, antes da fronteira de gênero, local de difícil aceitação social, a fronteira de raça já havia sido ultrapassada por Jerónimo, conforme podemos observar no seguinte trecho:

\footnotetext{
Mas, estranhamente: ela sempre ela, sempre Ezequiela. E Jerónimo a foi aceitando, transitável, mas intransmissível. No início, lhe custava esse acerto e reacerto. Mas depois até encontrou gosto nesse jogo de reencorpagem. E amava todas as formas, volumosas, translíneas, tamanhosas ou reduzidas. Até dava jeito: ele era o polígamo mais monógamo do universo (COUTO, 2016, p, 106).
}

A aceitação de Jerónimo reflete a miscigenação de um país como Moçambique, cuja formação é composta por diversas raças, como indianos, brancos e negros. Além destes, diversas etnias matrilineares e patrilineares convivem nesse país, como: os Macuas, Tongas, Nhanjas, 
Swahilis e Macondes. Com forte tradição cultural de diferentes raças, Moçambique reflete o conjunto étnico que constrói a identidade moderna desse país. Assim, o conto retrata a aceitação das diferentes raças, podendo ser interpretado como a humanidade que há por trás de cada rosto que Ezequiela metamorfoseia. Mia Couto parece tentar revelar a complexidade étnica de Moçambique.

Ultrapassadas essas fronteiras, a problemática aparece quando Ezequiela acorda metamorfoseada em homem: "Até que certa vez despertou a seu lado um homem, barbalhudo e provido de músculo" (COUTO, 2016, p. 106). Para Jerónimo, sua mulher se transformar em outras mulheres é compreensível, mas a forma masculina é algo inconcebível para ele. Como herança do pensamento colonial dicotômico e patriarcal, a separação entre os gêneros em Moçambique pós-colonial é bem delimitada. Jerónimo é colocado à prova, assim como o narrador de Mulher de mim, pois a ideia de que sua mulher seria também um homem, com todos os estereótipos que isso carrega, é algo intransponível e irracional: "Seria ela, integralmente, um ele?" (COUTO, 2016, p. 107). O medo de colocar em risco sua própria masculinidade e de ceder ao amor de sua esposa, enquanto corpo masculino, é uma grande barreira.

Jerónimo se viu desafiado por uma situação que contrariava seus ensinamentos. A lei ou estatuto social que dirige a sua vida foi alterada quando sua mulher se transforma em homem. O momento de transição e transformação se dá pela febre. Esta, assim como o fogo, é o elemento necessário para a regeneração/ressurreição do personagem. Purgado pelo fogo interior - a febre - Jerónimo abre os olhos para a nova realidade, tornando-se um novo homem (CANTARIN, 2012, p. 149).

Se o fogo aparece como elemento masculino e de regeneração do sujeito, a lua, mais uma vez, tem papel importante no enredo, pois é sempre à noite que Ezequiela se transforma. É no ambiente noturno que sua essência se preserva e seu exterior se transforma, abrindo espaço para o irracional. O luar, relacionado à feminilidade e entrega ao misticismo, é o ambiente da situação surreal que envolve o conto.

Mais ainda, é em outra noite que Jerónimo regressa doente para o lar e se deixa aos cuidados de sua esposa: "Aos poucos, o marido amoleceu. E quando sentiu os lábios de Ezequiela lhe beijando a testa até Ihe veio um gosto de adormecimento. E se abandonou mesmo estranhando um raspar de barba em seu pescoço" (COUTO, 2016, p. 107). Jerónimo ultrapassa os limites e valores de sua masculinidade, entregando-se aos cuidados de sua esposa ainda "em 
fase de macho". O inusitado se dá no desfecho do conto, após a entrega e reconciliação do casal, Jerónimo percebe uma mudança em si mesmo, quando não reconhece a si e a sua esposa:

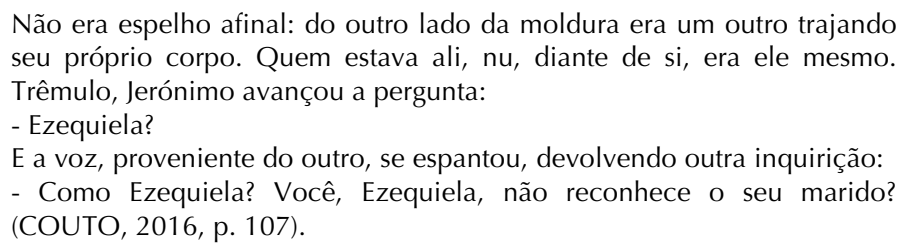

Não é uma troca de corpos apenas, um personagem passa a ser o outro, por isso o maior estranhamento e polissemia de desfecho, nessa narrativa. Se em Mulher de mim, o narrador conhece seu lado feminino, aqui, Jerónimo e Ezequiela passam a ser um só, completando o ciclo andrógino. De forma física, a mulher que já tinha em si a humanidade, passa a compartilhar o corpo de seu marido. É intrigante também a presença do espelho, no final do conto, em que Jerónimo não se reconhece mais. Para Herder Lexicon (1990, p. 88), o espelho é um objeto sagrado em diversas culturas, aparecendo como símbolo solar, por ser fonte de luz, e também lunar, devido à sua passividade. Liga-se ainda à feminilidade, verdade e sabedoria. Dessa maneira, o espelho não mostra apenas um, mas os dois sujeitos, masculino e feminino coexistindo naquele corpo. O espelho sugere ainda uma reflexão da nação moçambicana (plural e que, paradoxalmente, não consegue se enxergar com as diferenças).

O estranhamento da situação insólita de Ezequiela mostra-se como uma interseção entre política e arte, assim, a literatura ocupa um espaço de luta. O leitor, exposto ao estranho, vê a forma do corpo do personagem e o corpo moçambicano. Melhor dizendo, a personagem expõe literariamente o painel racial e de gênero, na sociedade ainda em formação. Jerónimo, assim como o leitor, hesita perante as diversas faces que constituem aquela mulher.

Os nomes dos personagens podem funcionar como antecipação ou indício de caracterização dos mesmos. Desde o título, o autor sugere uma caracterização de Ezequiela: que ela guarda em si toda a humanidade, em suas diversas etnias e cores. Além de ser um nome tipicamente masculino: Ezequiel, ela está em um lugar de ambiguidade. A estranheza que a forma feminina causa é semelhante ao curioso dom dessa mulher, carregado de encantamento e mistério.

Em ambos os contos, podemos observar o medo dos homens ao se depararem com o feminino, ou melhor de se enxergarem no feminino. Segundo Márcio Cantarin (2012, p. 150), há uma fragilidade na identidade de gênero em situações em que há mudanças nos papeis naturais. Na obra de Mia Couto, essas situações ocorrem com frequência, pois, estão presentes 
diversos homens que mergulham em suas profundezas psíquicas, encarando o medo da mortalidade e do feminino. Assim, seja mulher, seja água, ambas acesas pela lua, que revela o verdadeiro de todos os seres, sua feminilidade.

Esses contos têm em comum o tom de narrativa mitológica, fundadora de novos arquétipos. No projeto de Mia Couto, em tratar das fronteiras de raça, classe e gênero, as narrativas analisadas reconstroem a ideia de feminino e masculino, tornando as imagens complementares e não dicotômicas. Em Mulher de mim, o narrador se depara com sua feminilidade e busca dar espaço para sua mulher interior. Por sua vez, Ezequiela carrega dentro de si a humanidade, com as diversas nuances. Enquanto, Jerónimo, seu marido, ultrapassa as fronteiras e permanece ao lado de sua esposa, até se tornarem um só. Percebemos a união do masculino e feminino, por meio de simbologias, não mais opositivas e sim complementares.

Também na narrativa Joãotónio, no enquanto (2012), presente no livro Estórias abensonhadas, vemos outros personagens que se confundem entre o masculino e feminino. Joãotónio se apaixona e, rapidamente, se casa com Maria Zeitona. Porém, o casamento não é o que ele espera, pois, Zeitona é uma mulher frígida e, apesar das investidas do marido, a mulher permanece sem desejos sexuais, "como se fosse com uma defunta". É então que Joãotónio decide levar a esposa à prostituta Maria Mercante, para que aprenda os segredos do sexo. $\mathrm{O}$ cômico surge porque Maria Zeitona regressa com desejos sexuais, entretanto, executando o papel tipicamente masculino.

O narrador, Joãotónio, parece estar confessando sua história para um outro homem, utilizando repetidamente o vocativo "mano" durante sua narração. Inicialmente, desconcertado e com vergonha, ele conta o que se passou com sua esposa: "Porque não é um qualquer que publica assim as suas dores. O que vou escrever é motivo das vergonhas" (COUTO, 2012, p. 100). Maria Zeitona retorna ao lar combinando caracteres masculinos e femininos. O narrador utiliza ainda o adjetivo "manda-bátegas", uma espécie de hipérbole de "manda-chuva", tamanha a dominância e masculinização da mulher (ROTHWELL, 2015, s/p).

Constata-se a transitoriedade do narrador desde as primeiras linhas: "Por enquanto, sou Joãotónio" (COUTO, 2012, p. 99). A efemeridade de sua situação masculina culmina no desfecho quando se reconhece "Joãotónio e Joanantónia, masculina e feminino, nos braços viris de minha esposa". A inversão dos gêneros das palavras aprofunda ainda mais a fluidez dessa fronteira. A transição entre o que é socialmente associado ao masculino para aquilo que é feminino se dá lentamente, pois, no princípio, a relação entre homens e mulheres lhe parece ser uma batalha, como destacamos no seguinte trecho: 
E agora já ouço a sua pergunta: porquê esta mania de adivinhar suspiros? É a mesma vontade do general, mano. É o gosto de antecipar a rendição do adversário. É o desejo de antescutar como elas se podem requebrar, vencidas e abandonadas (COUTO, 2012, p. 99).

Isso reflete o pensamento que assume os limites entre os gêneros rigorosamente, atribuindo estereótipos para os sexos (ROTHWELL, 2015, s/p). Como dito anteriormente, a obra de Mia Couto é cheia de personagens que têm medo do feminino. Homens e meninos que se assustam com o ser feminino ou de se enxergar na feminilidade. No caso de Joãotónio, o feminino é encarado como inimigo, até o momento em que ele se reconhece feminino também.

Essa oposição dicotômica, lançada como verdade absoluta, é desfeita no decorrer da narrativa, pois, nas palavras do narrador, a verdade possui várias versões. Relacionando as mulheres à irracionalidade, ele justifica que suas ideias nascem fora do pensamento e esse é o fator de superioridade. O posicionamento maniqueísta do narrador é justificado no momento em que ele demonstra ter medo do feminino, observável no seguinte excerto:

\begin{abstract}
Às vezes, penso: no fundo, eu tenho medo de mulher. E você não tem? Tem, bem que eu sei. As ideias delas nascem num lugar que está fora do pensamento. Daí vem nosso medo: nós não deciframos o entendimento das mulheres. Suas superioridades nos medonham, mano. Por isso, as concebemos em tratos de batalha, versadas adversárias (COUTO, 2012, p. 99).
\end{abstract}

Cabe ressaltar ainda que não é apenas no quesito sexual que as mudanças ocorreram, o comportamento de Maria Zeitona se torna masculino em todos os âmbitos. Antes, Zeitona era quieta, submissa e introvertida. Tais comportamentos são associados ao caráter feminino. É ao voltar para casa, o que Joãotónio caracteriza como masculino, que a mulher passa a falar mais, dar ordens e exercer dominância. O autor cria o vocábulo "manda-bátegas", hiperbolizando "mandachuva", aquele que domina e comanda. A surpresa com o comportamento de Zeitona pode ser observada no seguinte trecho:

\footnotetext{
Passaram semanas, o curso terminado, minha esposa regressou a casa. Vinha, de facto, mudada. Seus modos eram demasiado estranhos, mas não da maneira que eu esperava. Caramba, mano, até ponho vergonha nesta confissão: Zeitoninha vinha com jeitos de homem! Ela que era tão metida nos ombros dela agora parecia uma manda-bátegas. Isto é, isto foi: minha Zeitona se inchara de masculina. E não era só no momento dos namoros. Era sempre e em tudo. Na voz, inclusive (COUTO, 2012, p.102).
}

Observa-se, por consequência, ainda uma mudança crescente de Joãotónio, pois, gradualmente ele muda seu posicionamento de vergonha para aceitação da felicidade ao lado de sua esposa. Se esta regressa tão diferente que é quase um homem, o esperado é justamente 
que Joãotónio torne-se feminino: "O problema, mano, é o seguinte: eu até gosto! Me custa admitir, tanto que hesito em escrever. Mas a verdade é que me agrada esta nova condição, sendo-me dada a passiva idade, o lugar de baixo, a vergonha e o receio" (COUTO, 2012, p. 102).

Se a postura de Maria Zeitona muda, o tratamento de seu marido também. Percebemos isso pela mudança de nomes que ela sofre no decorrer da narrativa: Maria Zeitona, Zeitona, por fim, Zeitoninha. Esse gradativo carinho com a esposa sugere a inversão de papeis entre o casal, pois, enquanto Zeitona se masculiniza, Joãotónio torna-se mais delicado e carinhoso. O uso do diminuitivo, com carga afetiva, sugere que o narrador está feliz com sua esposa e não ofendido com seu comportamento dominante.

Segundo Pierre Bourdieu (2002, p.16), o mundo social vê o corpo como "realidade sexuada e depositário de princípios de visão e divisão sexualizantes". Sendo assim, a ordem social é desmistifica nessa narrativa de Mia Couto, pois os papeis de dominador e dominado são invertidos, enquanto os sujeitos brincam com as oposições entre masculino e feminino.

Ressaltam-se os termos utilizados para representar a condição, antes feminina, agora ocupada por Joãotónio: a passiva idade, o lugar de baixo, a vergonha e o receio. Na representação do pensamento sexual do narrador, estas deveriam ser as posições femininas, submissas e passivas. Com a inversão de papeis, cabe a ele, homem, ocupar esse lugar inferior: "Ela é que me empurrava a deitar, acredite, ela é que me desapertava, me ia roubando os ares. Eu ficava para ali sem nenhuma iniciativa, executado e mandado como se fosse rapariga iniciada" (COUTO, 2012, p. 102). Tamanha é a surpresa pelas novas maneiras de Zeitona que Joãotónio necessita coçar suas partes íntimas para assegurar sua masculinidade.

Entretanto, mais adiante, o narrador subverte ainda mais os papeis femininos e masculinos quando defende: "nos amores sexuais não há macho nem fêmea. Os dois amantes se fundem num único e bipartido ser. Não haveria, portanto, razões para meu rebaixamento" (COUTO, 2012, p. 103). Novamente, retomamos a imagem do andrógino, aqui utilizado como símbolo do ato sexual, onde os corpos se unem na formação de um único ser total e pleno. Mais que uma alternância de papeis, podemos perceber uma igualdade, uma desintegração dos papeis por gênero, onde não há macho, nem fêmea, mas um ser em toda a sua completude.

Em diversas culturas e mitologias, o ato sexual é descrito como uma relação de dominância, submeter ao poder ou possuir. Bourdieu (2002, p. 28), citando o mito de criação do povo de Cabília, norte da Argélia, defende que as manifestações de virilidade se ligam ao sujeito masculino. Nessa ordem cósmica, as mulheres são naturalmente instruídas aos assuntos do amor, mas a dominação masculina é a hierarquia fundamental. Podemos inferir que, na 
narrativa coutiana, há uma desconstrução dessa visão hierarquizada, pois as práticas e representações do ato sexual podem ser simétricas, não havendo macho, nem fêmea.

Mais uma característica ligada ao feminino é ressaltada no desfecho do conto: a irracionalidade. Joãotónio enquadra a masculinidade no mundo racional e a feminilidade no espaço da irracionalidade. Por isso, como dito anteriormente, há o medo causado pelas mulheres, pois, estas concebem as ideias em um lugar fora do pensamento. No processo de feminização do narrador, é justamente o distanciamento da razão que Joãotónio deseja, pois, as explicações tradicionais não abarcam sua situação atual. O trecho abaixo ilustra o que foi dito:

\begin{abstract}
Mas agora, no momento que Ihe escrevo, nem mais me apetece explicação. Quero desraciocinar. Em cada dia não espero senão a noite, as brandas tempestades em que eu sou Joãotónio e Joanantónia, masculina e feminino, nos braços viris de minha esposa. Por enquanto, mano, ainda sou Joãotónio. Me vou despedindo, vagarinhoso, do meu verdadeiro nome (COUTO, 2012, p. 103).
\end{abstract}

O narrador se despede de seu verdadeiro nome e assume sua transitoriedade, sendo masculina e feminino, Joãotónio e Joanantónia. Apesar da tentativa de classificar e enquadrar os sujeitos em categorias de gênero e normas regulatórias, nesse conto, os indivíduos escapam dessas classificações, permanecendo em constantes flutuações daquilo que é, culturalmente, feminino e masculino.

Joãotónio se depara com novas experiências, com a redescoberta de seu anima e o encontro com o seu Yin. Além de sua relação com Maria Zeitona, o narrador lida consigo mesmo, sua individuação e seu reconhecimento feminino. A desconstrução da imagem de homem e mulher se dá lentamente, na mudança de pensamento do narrador e aceitação da efemeridade, presente desde o título, "Joãotónio, no enquanto".

Todos os personagens aqui analisados encontram-se no espaço da ambiguidade e da flutuação entre masculino e feminino. A aceitação daquilo que é masculino e feminino em todos os seres, dos arquétipos de anima e animus, coloca em xeque a ideia de que há um papel predeterminado para homens e mulheres, definido por questões biológicas. A travessia dessa fronteira, assim como as de raça, classe social e cultural, é contínua e transitória, pois trata-se de uma lenta construção.

\title{
Referências
}

BACHELARD, Gaston. A poética do devaneio. Tradução: Antonio de Pádua Danesi. São Paulo: Martins Fontes, 1996. 
A Água e os Sonhos: ensaio sobre a imaginação da matéria. Tradução: Antonio de Pádua Danesi. São Paulo: Martins Fontes, 1989.

BOECHAT, Walter. Mitos e arquétipos do homem contemporâneo. Petrópolis: Vozes, 1995.

BOURDIEU, Pierre. A dominação masculina. Tradução: Maria Helena Kühner. 2 ed. Rio de Janeiro: Bertrand Brasil, 2002.

BRAÇO, António Domingos. Narrativas culturais e as identidades de gênero em Moçambique. Gênero na Amazônia, Belém, n. 06, jul./dez. 2014. p. 259-273.

CANTARIN, Márcio Matiassi. Por uma nova arrumação do mundo: a obra de Mia Couto em seus pressupostos ecosóficos. São Paulo: Cultura Acadêmica, 2012

Mia Couto: beligerâncias e transgressões na fronteira dos gêneros. Revista Terra Roxa e outras terras. v.18. Out 2010. p. 89-99.

CHAVES, Raquel Costa. A palavra em transe: o sonho e o silêncio em Mia Couto. Dissertação (mestrado) UFMG, Programa de Pós-Graduação em Estudos Literários, Belo Horizonte, 2012.

COUTO, Mia. Contos do nascer da terra, São Paulo: Companhia das Letras, 2014.

Cada homem é uma raça. São Paulo: Companhia das Letras, 2013.

Estórias abensonhadas. São Paulo: Companhia das Letras, 2012.

O Fio das missangas. São Paulo: Companhia das Letras, 2009

Na Berma de Nenhuma Estrada. São Paulo: Companhia das Letras, 2001.

ELIADE, Mircea. Imagens e símbolos: ensaios sobre o simbolismo mágico-religioso. Tradução Sonia Cristina Tamer. São Paulo: Martins Fontes, 1991.

JUNG, Emma. Anima e Animus. São Paulo: Cultrix, 2006

LE BRETON, David. A sociologia do corpo. Tradução: Sonia M. S. Fuhrmann. Petrópolis: Vozes, 2009.

LEXIKON, Herder. Dicionário de símbolos. Tradução: Erlon José Paschoal. São Paulo: Cultrix, 1990.

PLATÃO. O Banquete. Tradução de Donaldo Schuler. Porto Alegre: L\&PM, 2012.

QUELHAS, I. T. G. Identidades e eventos: uma leitura de Mulher de mim, de Mia Couto. Revista Letras \& Letras, Portugal, v. 1, p. 1-15, 2001.

REIS, Carlos. Dicionário de Teoria Narrativa. São Paulo: Editora Ática, 1988.

ROTHWELL, Phillip. Leituras de Mia Couto: aspectos de um pós-modernismo moçambicano. Tradução: Margarida Calafate Ribeiro. Coimbra: Edições Almedina, 2015.

. Os jogos de gênero em três contos de Mia Couto. In: RIBEIRO, Margarida Calafate; MENESES, Maria Paula. Moçambique: das palavras escritas. Porto: Afrontamento, 2008.

TEIXEIRA, Rafhael Peixoto. Uma imagem entre as veredas do grande sertão: Diadorim e a construção da androginia. Dissertação (mestrado) - UEFS, Programa de Pós-Graduação em Estudos Literários. Feira de Santana, 2016

Recebido em 12/04/2019.

Aprovado em 17/05/2019. 